\title{
The Future for Wildlife in the Sudan
}

$$
\text { By D. C. D. Happold }
$$

The Government is unaware of the value of wild animals; the people mostly regard them as inferior sorts of cow to be eaten or got rid of; the Game Department struggles to guard them with inadequate staff: what should be done? The author, a zoologist who has spent three years at the University of Khartoum*, surveys the situation, comments on the recommendations in the Fraser Darling Report, and concludes that, if the Sudan is to become one of the principal game countries in Africa, as it should be, some at least of these recommendations must be implemented in the next five to ten years.

THE Sudan is the largest country in Africa, nearly a million square miles. Within its borders are desert, semi-desert, savanna, tropical forest, swamp and mountain. The immense variety of habitat and climate is reflected in the variety of the fauna, and although this has not been studied as extensively as in some other African countries, there are good systematic lists of the mammals ${ }^{24}$ and birds $^{8}$, and scattered publications on other groups. The larger fauna, however, is disappearing rapidly, and the last thirty years have seen a big reduction in the numbers and range of many species. It is more urgent now than ever before to conserve these larger animals in national parks and reserves, or by other means. General information about conservation and national parks in the Sudan is very limited, especially when compared with East Africa: a recent survey of national parks and reserves in the world by Engelhard $\mathrm{t}^{12}$ gave no details for the Sudan. The object of this paper is to give an historical survey of conservation in the Sudan, to describe the present status of parks and reserves, and to make suggestions for the future.

\section{Historical Background}

The Sudan was one of the first African countries to establish protected areas for wild animals. In the Preservation and Will Animals Ordinance of $1903^{11}$ two reserves were established between the Blue and White Niles where "no person other than natives of the Sudan residing in the said Sanctuary, and Officers and Officials stationed in the same and having a special permit endorsed on their licence, shall hunt, capture or kill any will animal or bird". There were also Schedules for protected and partially protected species, and hunting regulations in this Ordinance. In these early days, all travellers remarked on the wealth and abundance of game, and many of them

* The author is now at the University of Ibadan, Nigeria. 


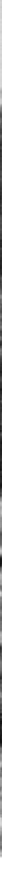

\section{Plate 4. A river in the Nimule National Park. SCENES IN THE SUDAN}

Plate 5. Jebel Marra: the lake in the crater.

P. G. Molloy

D. C. D. Happold 


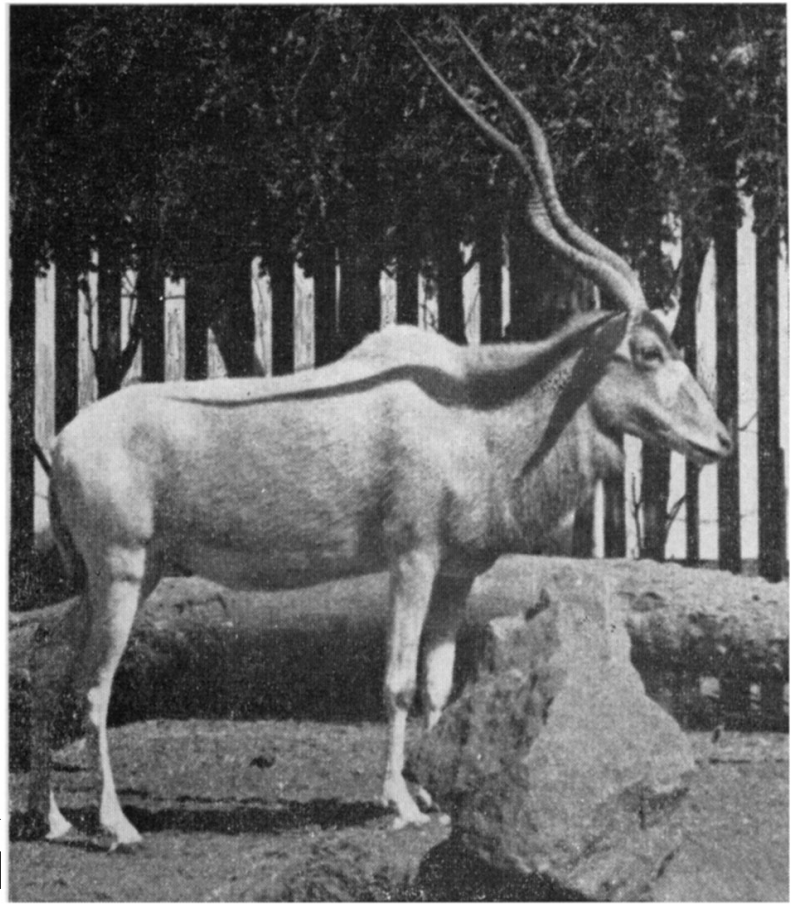

\section{THE SUDAN}

Plates 6 and 7.

Addax in Khartoum Zoo. Once common in Darfur Province, this desert antelope is now rare and still decreasing.

Below : Crossing the dried-up Dinder river to the island in the middle, with Galegu camp in the distance on the right.

Photographs by D. C. D. Happold

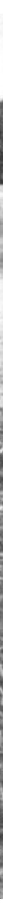




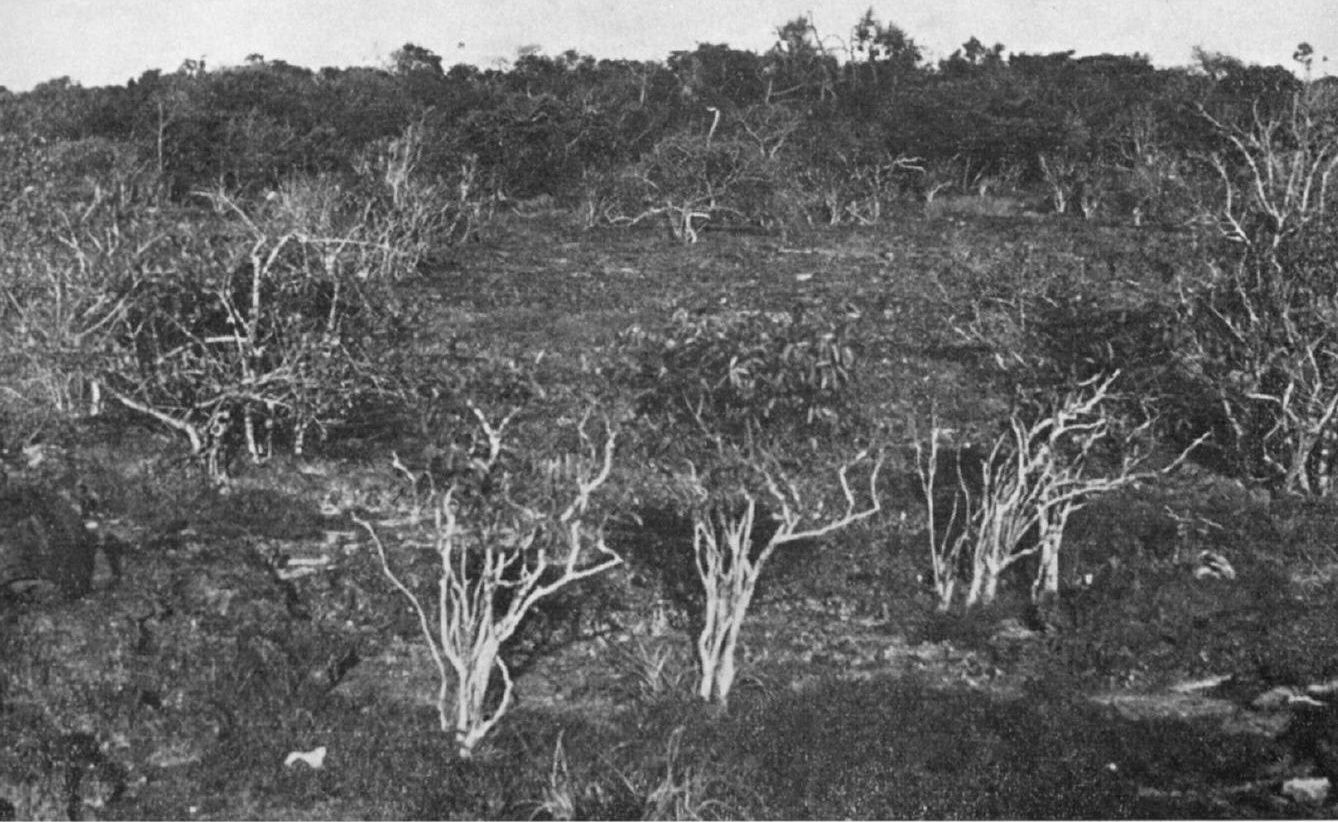

\section{ALDABRA-A CORAL ATOLL AND ITS WILDLIFE} Photographs by Roger Gaymer

Plate 8 top: South Island. Plate 9 below: Giant Tortoise and Sacred Ibis.

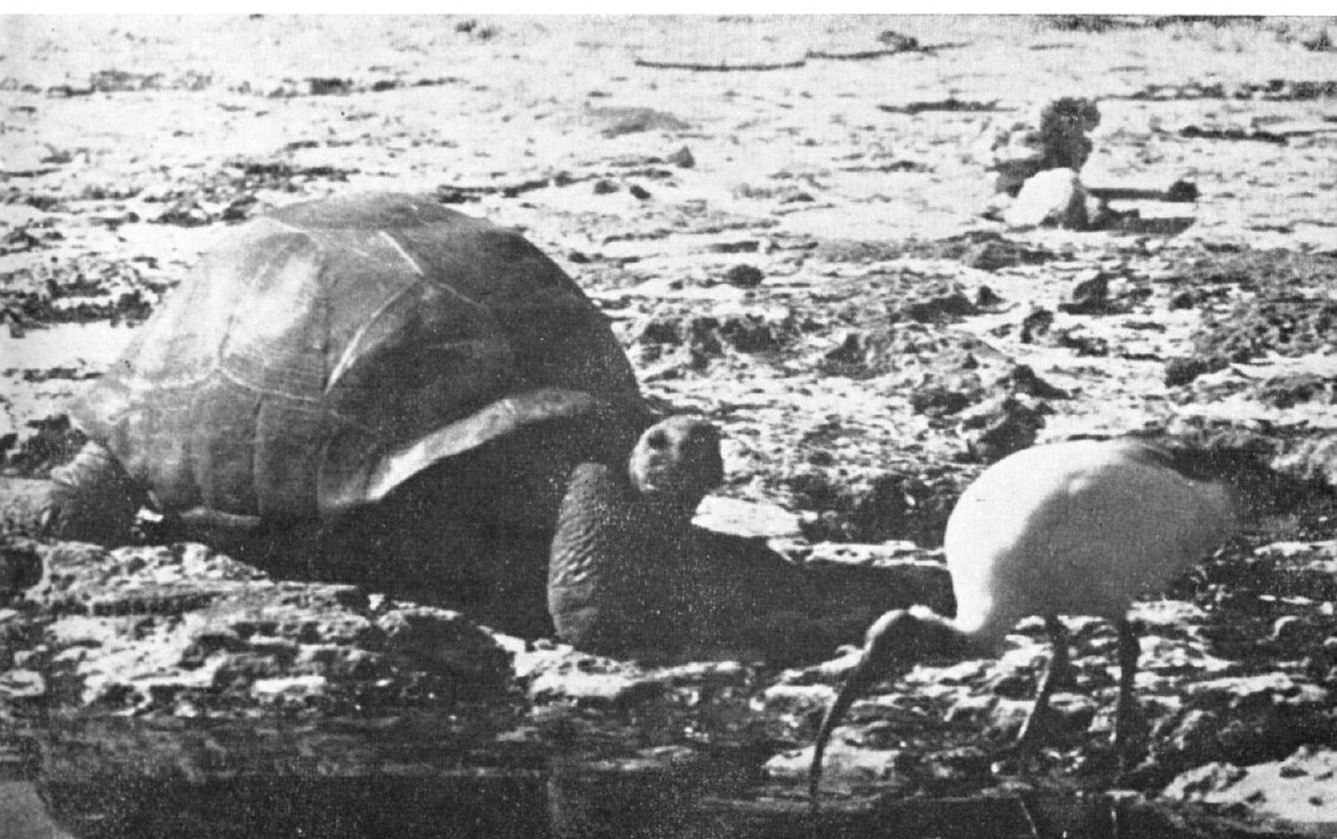




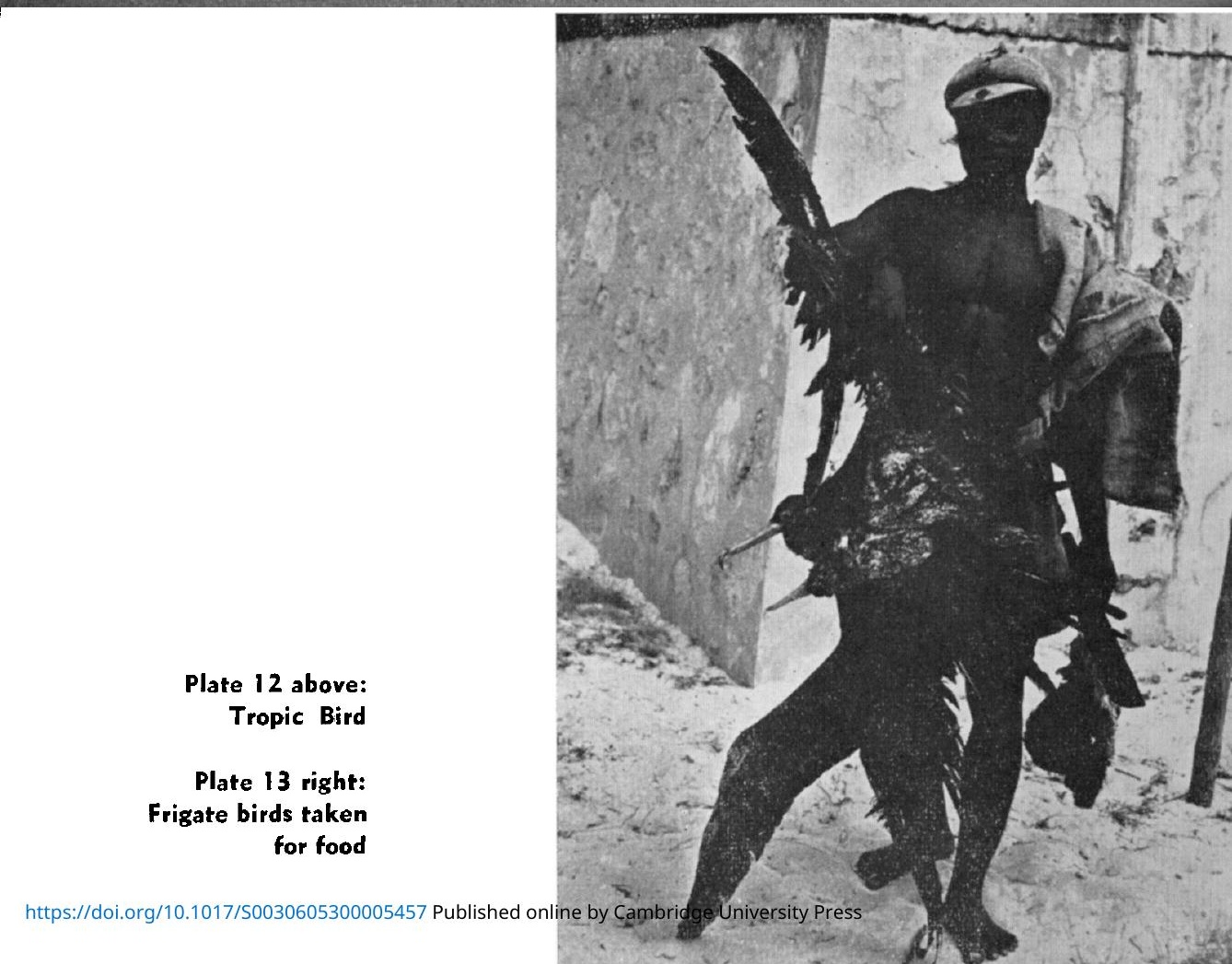




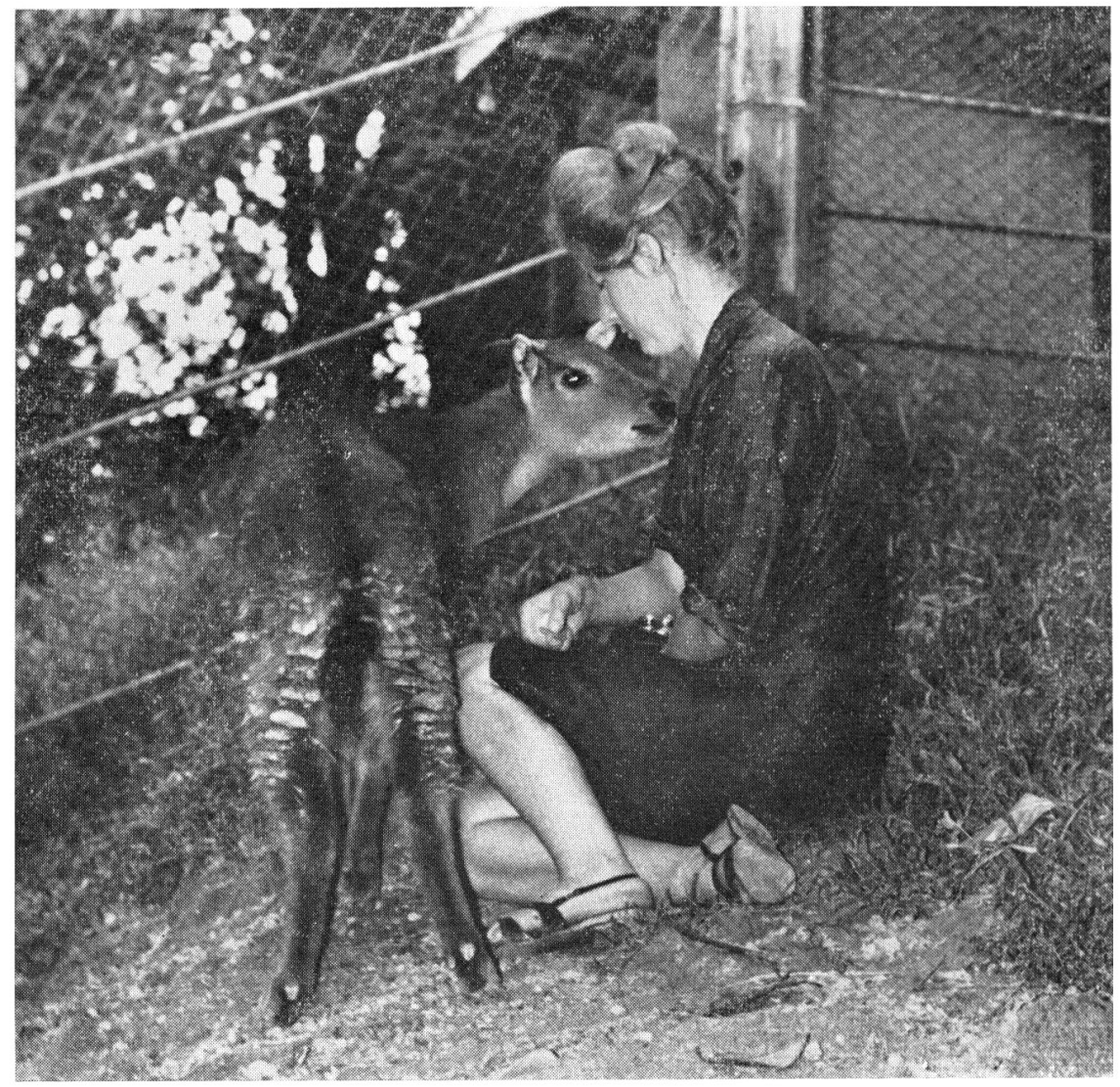

Plate 14

THE RED GORAL

One of the first photographs to be published of a red goral Naemorhedus cranbrooki from Burma, named as a new species as recently as 1961. In 1931 Lord Cranbrook, on a plant hunting expedition with Kingdon Ward, saw one of these gorals, recognised it as a new form and shot it; the British Museum have named it in his honour. Though nothing is known of the red goral's numbers in the wild, it is not rare, but it is rarely seen owing to the remoteness of the mountainous areas in northern Burma where it lives. This female in the Rangoon Zoo was captured near Lashio in January 1964, and is seen with Caroline Jarvis, editor of the International Zoo Yearbook, to whom we owe the photograph. The red goral has a bright foxy red coat, and differs from other gorals in having shorter softer hair, no pale throat or chest patch, and a blackish dorsal stripe extending to the root of the tail. Like all these "goat-antelopes" of the mountains it is exceedingly agile. An account of the Red Coral and a colour photograph of the skin can be found in the Proceedings of the Zoological Society of London, May 1961, Vol. 136, 317. 


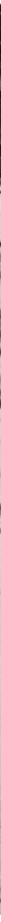

Plate 15

E. P. Gee

\section{SUMATRAN RHINOCEROS}

The smallest of the world's five species of rhinoceros, it is believed that well under 200 survive in the wild. This female in Copenhagen Zoo, caught in Sumatra in August 1959, is now about 14-15 years old and the only one in captivity in the world. An article on the Sumatran rhino in Malaya, where only ten are certainly known, is on page 353 . 


\title{
THE MOORLAND GALLERY
}

(SPORTING \& WILDLIFE PAINTINGS LTD.)

23 CORK STREET, BOND STREET LONDON, W.1 REGent 6961

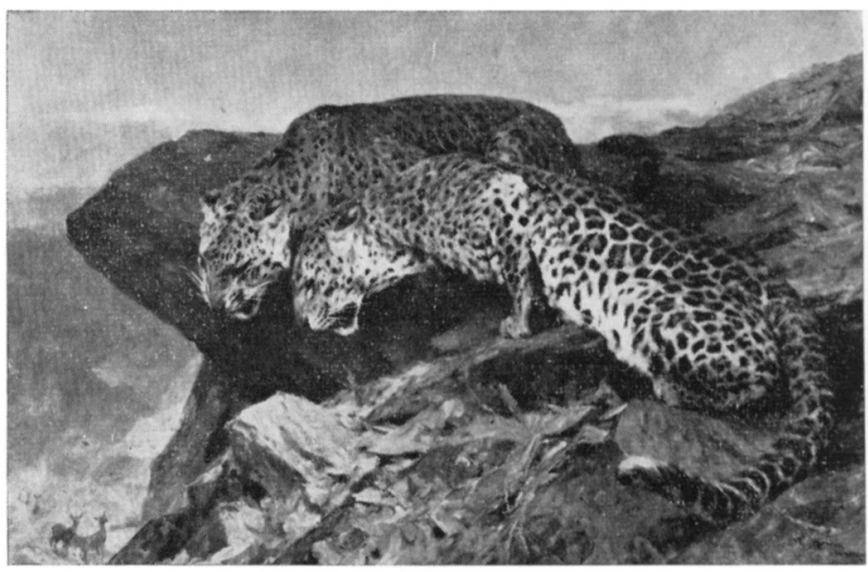

"THE ST ALKERS"

Arthur Wardle, R.I., R.B.A. $\left.\left(31^{\prime \prime} \times 42 \frac{1}{2}\right)^{\prime \prime}\right)$

\author{
BIG GAME \& WILDLIFE \\ OIL PAINTINGS and WATERCOLOURS
}


recorded interesting observations on the natural history of various species ${ }^{18,9}$, 27, 11. Game Animals of the Sudan ${ }^{5}$, a classic on Sudanese game, described and illustrated all the larger animals. In those days it was difficult to imagine that the vast herds of wild animals might disappear, and a Handbook published in 1911 states that "the present condition and outlook for the near future appear to be very satisfactory. There are large areas in the Sudan which are not likely ever to be populated, and where the continued existence of game in abundance can be secured by adequate pnotection. In such districts, there is no reason why large game should not continue to exist for centuries . . ."

One of the most spectacular sights described by these early observers was the game migrations, particularly in the southern provinces. In the Ilembi triangle, in the south-east, the migrating herds were on a scale similar to those in the Serengeti ${ }^{\tau}, 10,17,27$. Whalley described one game trail where tiang, giraffe, lesser eland, beisa oryx, Grant's gazelle and Mongalla gazelle passed by at 20-30 per minute for $4 \frac{1}{2}$ hours ${ }^{27}$, and another report estimated that one line of migrating game was 25 animals wide and $1 \frac{1}{2}$ miles long ${ }^{7}$. And sometimes these migrations went on for days ${ }^{10}$. The animals move south and south-east from the Sudd in May at the beginning of the rains, and return northwards again in October-November, but there are no really detailed observations on the migrations because during the rains it is almost impossible to travel in the llembi triangle. How extensive the migrations are now, or what numbers of animals are left is unknown, since there have been no reports in recent years ${ }^{28}$.

In 1933, at the time of the International Congress on Protection of Fauna and Flora, the Sudan was one of the foremost African countries in game conservation. Major W. R. Barker, the Game Warden, was one of the four delegates from Africa to the Congress (South Africa, Egypt, Abyssinia, Sudan). Two years later, in 1935, a new Wild Animals Ordinance and Regulations were published, and in 1939 the National Parks, Sanctuaries and Reserves Regulations were gazetted. Except for minor alterations (1960) both are still in force today ${ }^{25}$. At present there are three national parks, three Sanctuaries and fifteen Game Reserves (Table 1). Some of these are certainly effective in preserving the game, but the value of others, especially where there is inadequate patrolling, is dubious. Little has been published on the status of the wild animals and the national parks in the last ten years, and few people outside the country are aware even of the existence of the Sudan Parks or of the variety of animals there. Since international interest and tourism can have such a beneficial effect on wildlife preservation, this can have an adverse effect on the game.

The most important event for conservation in the Sudan in recent years was Dr. F. Fraser Darling's visit in 1961, at the Sudan Government's request, to advise on the country's wildlife ${ }^{13}$. But his report, which was not published as a Government Paper, has not received 
TABLE 1.-National Parks, Game Reserves, and Sanctuaries in the Sudan administered by the Came and Fisheries Department.

\section{National Parks}

1. Dinder

2. Southern

3. Nimule

\section{Game Reserves*}

4. Tokar (x)
5. Rahad (x)
6. Sabaloka (2)
7. Fanyikang Island (x)
8. Zeraf (x)
9. Boma (2)

10. Badigeru (x)

11. Mongalla (2)

12. Juba (x)

13. Mbari-zunga (1)

14. Bire Kpatuos (1)

15. Bengengai (2)

16. Shambe (x)

17. Numatina (2)

18. Ashana (2)

\section{Sanctuaries}

19. Nile from Khartoum

20. Sinkat/Erkowit to Gordon's Tree

21. Erkowit
Sq. miles

2750

6500

100

2800

200

100

150

1500

2000

374

30

120

100

\section{$?$}

250

400

750

50
Province

Blue Nile

Equatoria

Equatoria

Kassala

Kassala

Khartoum

Upper Nile

Upper Nile

Upper Nile

Equatoria

Equatoria

Equatoria

Equatoria

Equatoria

Equatoria

Bahr-El-Ghazal

Bahr-El-Ghazal

Bahr-El-Ghazal
Game

Tiang, waterbuck, reedbuck, otc. Elephant, rhino, eland, many ungulates.

White rhino, elephant, etc.

Ibex, gazelle, wild ass.

Similar to Dinder. Barbary sheep.

Nile lechwe, kob.

Nile lechwe, elephant, buffalo. Many E. African spp.

Elephant, buffalo, reedbuck.

Buffalo, bushbuck, reedbuck.

Same as

Mongalla.

Buffalo, waterbuck.

Bongo, forest

fauna.

Plains and forest fauna.

Nile lechwe

elephant.

Similar to

Southern NP.

Eland, buffalo.

(From National Parks, Sanctuaries and Reserves Regulations 1939, and Schomber 1962)

Figures 1-21 before the names refer to the areas marked 1-21 on the map opposite.

* Figures in brackets after the name of each reserve indicate the number of game scouts employed there; $(x)$ means there are no permanent scouts, and these reserves are supervised by wardens and scouts as part of their duties. 


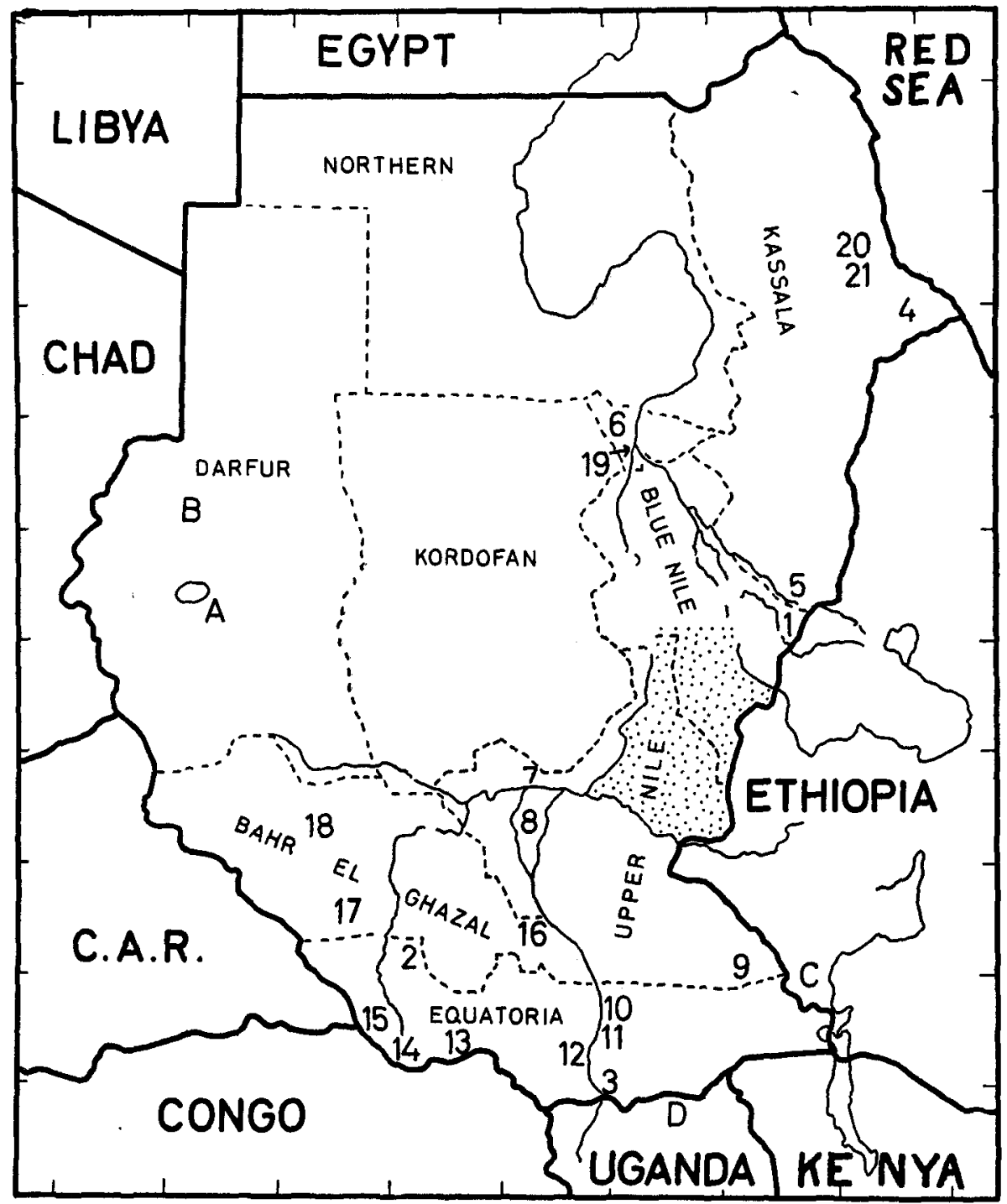

National Parks, Game Reserves and Sanctuaries in the Sudan.

The numbers 1-21 refer to the protected areas listed in Table 1 opposite. Other areas mentioned in the text are $A)$ Jebel Marra, B) the region suggested for a reserve for addax and oryx, C) the approximate position of the proposed Omo National Park in Ethiopia, and D) the Kidepo National Park, Uganda. The stippled area between the Blue and $W$ hite Niles is the region originally declared as a reserve in 1903, but now repealed. 
the attention that it merits, and none of its nine recommendations has been implemented. These recommendations (in bold type) are:

\section{There should be an overall land-use policy.}

It is essential that the national parks and reserves should fit in with a national land-use policy if the parks are to fulfil their functions. Where there are conflicting interests, the correct policy is the one which preserves the land in the best interests of the nation. Human and animal rights often conflict, but the Sudan still has a small population in relation to her size, so that it should be possible to have parks and reserves that do not infringe human rights. But in a few years time an increased population, more domestic animals, and pressure for more irrigation schemes may make it difficult for the parks to survive. They are not considered sufficiently important yet to withstand such pressure; hence a great effort is required now to ensure their safety in the future.

\section{The Game Department should recruit scientific staff to work on biological problems related to game conservation.}

The Game and Fisheries Department Director, Mirghani Mekki Medani, is responsible for administering all protected areas, and for controlling all hunting. Until recently the Depantment was an offshoot of the Veterinary Department-an unsatisfactory arrangement-but now that Game and Fisheries is an independent Department, more progress should be possible. Considering the responsibility they have, the Game Department, under the Assistant Director (Game) Mahmoud Abu Sineina, is seriously under-staffed. A comparison of the staff in the Uganda and Sudan national parks emphasises this, even though Uganda parks are more advanced and require a relatively larger staff. The number of wardens and rangers per square mile in the Sudan national parks is one in 20 in Nimule, one in 143 in Dinder and one in 400 square miles in the Southern park. In Uganda the comp.rable figures are: for Queen Elizabeth park one in 12, Murchison Falls one in 28, and Kidepo one in 11 square miles, and if other field staff are included the discrepancy becomes even greater. In the reserves, too, there is a similar staff shortage and therefore inadequate patrolling (Table 1); some have no regular staff at all. In the Provinces there are also Game Officers and Scouts whose job is to enforce the game laws and to look after the game not in preserved regions. Partly because of the staff shortage, the Game Department does not have any staff whose sole job is research in the parks. No University of Khartoum graduates in zoology have been recruited into the Game Department in the last few years, and it is doubtful if this occupation would be considered a suitable job by many graduates. Yet it is essential for the policies of the parks to be put on a scientific basis, and one day there should be research institutes similar to those in the Serengeti and Queen Elizabeth Parks. 
3. The Sudanese should be made aware of the value of their national heritage, and the importance of the national parks should be made known to both them and the outside world.

Information on game and national parks is almost non-existent. The Sudanese people, with some important exceptions, regard game as meat, and only an enlightened few realise the full value of wild animals. The small, well-kept Zoo at Khartoum attracts many Sudanese and is useful for educational purposes. There could be a short course for students on the importance of conservation, and primary and secondary schools should be encouraged to study more natural history in the field. People outside the Sudan can only learn about the parks if there is a good information service, periodic publications, and tourist literature. At present none of these exist. There is no tourism to speak of in the Sudan. One safari firm has started tours into the Dinder National Park this year, and as the Park is rather inaccessible this is the easiest method for most people. (See Appendix.)

\section{A national park or reserve should be established in northern Darfur to protect the addax and oryx, and another, on British or American lines, in Jebel Marra in Darfur. The status of Nimule National Park should be re-examined.}

Darfur Province is the westernmost Province of the Sudan adjoining Chad and Libya. Until the railway reached Nyala in 1961 it was one of the remotest parts of the country. Addax Addax nasomaculatus and scimitar-horned oryx Oryx tao were once quite common in the northern regions of the Province ${ }^{3}$, but now both species are greatly reduced, mainly because certain tribes, notably the Kababish, hunt them with firearms ${ }^{23}, 26$. If the present trend continues both animals may share the fate of the Arabian oryx. Any form of wildlife that is potential food is hunted, and reliable reports during the last year suggest that the hunting pressure has not been reduced. At present, neither species receives any protection other than being on Schedule II of Protected Animals (may be taken under special licence), which cannot be enforced. Since the addax and scimitar-horned oryx are on the IUCN's list of rare or endangered mammals, a reserve with sufficient wardens and scouts to give total protection should be established in the very near future, and both species should be placed on Schedule I (total protection).

Jebel Marra, in the centre of Darfur Province, is an extinct volcano rising to nearly $10,000 \mathrm{ft}$. The lower slopes are tree-covered; in the centre is the crater with two lakes surrounded by rolling hills of grass and bushes. Jobel Marra is without doubt the most beautiful region in the Northern Sudan, its cool climate and green countryside a stimulating contrast to the arid semi-desert, and interesting biologically because of certain endemic plants and animals ${ }^{14}$. During the last four years, the United Nations Special Fund has been surveying the Jebel with a view to starting irrigation schemes on the lower slopes, and 
possibly a dam in one of the larger "wadis". The Forests Department have several plantations of eucalypts and conifers. Whatever happens, the higher regions which form the watershed must be preserved intact. Mahmoud Abu Sineina informed me that he would like to see the higher region declared a Game Reserve to protect the kudu, but, in my opinion, this is insufficient. Because of its biological interest, importance as a watershed, outstanding scenery and potential tourist attraction, some part of Jebel Marra should be a National Park.

\section{The principles of wildlife management should be adopted in the parks.}

Because of the lack of staff, especially biological field staff, and the underdeveloped state of the national parks, wildhife management cannot be practised yet. But as more biologists become available scientific study of the main species and management, if necessary, should be possible, and this should be kept in mind as one of the important tasks of the Game Department.

\section{The Game Ordinance, particularly the hunting schedules, should be revised.}

Fraser Darling stated that the Wild Animals Ordinance 1935 and Game Regulations 1935 were out of date. (The 1960 amendments state only that the Minister of Animal Resources delegates his power to the Director, Ministry of Animal Resources.) The hunting schedules suggest a Sudan that is teeming with game, which is no longer true. He considered that "revision and severe curtailment of this schedule (is) one of the most urgent administrative steps to be taken", and suggested that game regulations of other African countries should be examined to see where their ideas can be adapted for use in the Sudan.

Large game is placed on one of three Schedules (Table 2). Schedule I animals are completely protected and may only be taken under exceptional circumstances with the permission of the Director of Game and Fisheries; Schedule II animals are protected but may be taken provided a special licence is obtained; Schedule III animals may be i $a \mathrm{k}: \mathrm{n}$ with firzarms as detailed in the ordinary licence, but no licence is necessary if these animals are hunted by certain traditional hunting methods. The ordinary licence is divided into six classes depending on where the licensee may shoot and for how long. The holder of a $£ 6$ Class $C$ licence may shoot 53 animals of 16 species, whereas with a $£ 60$ Class $A$ licence he may shoot only 106 animals, although of 31 species. Since these are the most important classes, they should be revised to make them more realistic. Fraser Darling suggested that the total number of animals in Class A should be reduced to 54; that the lesser eland, hippopotamus, lesser kudu, leopard, oryx, Chanler's reedbuck and wild sheep should be removed from the hunting schedule, and that Class $C$ should be reduced to 26 animals to allow the depleted stocks to build up. The ordinances in their present form are ambiguous. 
7. Lion and buffalo should be regarded as "game" so that the Game Department controls all hunting.

Lion, buffalo, and hyaena do not occur in the lists of protected animals; they are therefore classified as "vermin" and may be shot by anyone without a licence. All three species ought to be given some measure of protection so that their hunting can be regulated. Mahmoud Abu Sineina tells me that lion and buffalo may be placed on the schedules, but that hyaenas are still regarded as "vermin".

8. Inhabitants of wildlife areas should participate in the conservation of their game as in other parts of Africa.

As far as I know, there is no active participation by local inhabitants in the conservation of their wildlife. In the Sudan it would be impossible to make this new idea attractive until the local people can benefit from their conservation measures. At present a wild animal is generally regarded as a rather poor sort of cow, to be got rid of. A change in outlook is dependent on education, tourism and enlightenment.

9. Wildlife areas for use by professional hunters should be organised so as to ensure conservation of the game.

Much of the hunting is done in the southern half of the Sudan. In the last three or four years, with the three southern provinces closed to visitors for political reasons, the hunting pressure has been reduced; a safari firm that regularly took visitors to the south has not operated there for over three years. The idea of allocating areas of land to professional hunters as a methold of conservation may be a good one, but there has been no opportunity to try it in the Sudlan.

The Present Situation

The main reasons for the present situation are the lack of staff in the Game Department, particularly biologists to work on wildlife problems, and the attitude of the local people to their game. The Sudan has had a difficult period, politically and economically, during the last four years, so that time, thought and money have gone into more urgent problems. The three closed southern provinces, Equatoria, Bahr-el-Ghazal, and Upper Nile, which contain two of the three parks and thirteen of the fifteen reserves, are the most valuable for wildlife. No information on the state of these parks and reserves or the game has been published, but the fighting and general state of disorder cannot have been conducive to game protection or enforcement of the game laws.

The Nimule National Park, on the east bank of the Nile adjoining the Uganda border, lies, says Schomber, "in (a) heavenly landscape, described by those who know their Africa, as one of the most beautiful regions in this part of the world"'23 It was originally declared a protected area to protect the square-lipped rhinoceros Ceratotherium simum cottoni, the national emblem of the Sudan ${ }^{21}$. The Southern National Park is the largest, 6,500 sq. miles, and the most difficult to 
visit. Although Schomber lists giraffe, buffalo, roan antelope, waterbuck, bushbuck, kob, tiang, Lelwel hartebeest and lion as "plentiful" species $^{23}$, both Anderson ${ }^{1}$ and Molloy ${ }^{19}$ have questioned the validity of the Park. Anderson suggests that certain other areas in the southern Sudan would be more suitable, and that the limited money available could be put to better use, and Molloy considers that the region was made a park, even though it had little game, because it appeared to have no other value in the foreseeable future. But such a large region fulfils many of the essential requirements of a park and the whole region is a good example of this type of country.

The Dinder National Park, on the Ethiopian border, to the east of the Blue Nile, is the most accessible of the three. Even before a park was declared, this region was well known for its game, with species not seen normally in other better known parks to the south. But the game is not really secure. Although poaching from Ethiopia has been reduced in recent years, the local people are unsympathetic and insist on removing the park entrance and boundary sign. But the most serious threat is the proposed Rahad canal running from the new Roseires Dam north-eastwards into the Rahad river, near the northern boundary of the park. The waters will flow down the Rahad allowing permanent irrigation and cultivation. For the game moving northwards from the park in the wet season the canal will be an uncrossable barrier, and this may have adverse effects on the populations. This is a good example of a project in which all the interests of the region were not considered; irrigation always has priority even though the game stocks may, in the long run, be a more valuable material asset.

The three sanctuaries in the Sudan where "no animal whatsoever shall be hunted, killed or captured"25 afford greater protection than the parks and reserves (Table 1). The sanotuaries near Erkowit are presumably to protect the Nubian ibex and wild sheep, and the one on the Nile south of Omdurman protects migratory water birds and many of the local northern Sudanese birds ${ }^{2}$, although I have met several hunters who were not aware of the Nile sanctuary, and on several oocasions found used cartridges by the water there.

There are many forest reserves administered by the Forests Department, especially in the south, which are in effect wildlife reserves although wildlife protection is not specifically mentioned in the Forests Department Statutes. Entry without a permit and hunting are forbidden, and the legal status of proteoted animals is enforced by forest rangers (Shawki, pers. comm.). Where animals are doing damage, the interest of the forest takes precedence, but in fact, most forest reserves, even in northern regions, act as wildlife refuges and are an important addition to the parks, reserves and sanctuaries. There are also two Nature Reserves, both in Equiatoria: the Lotti Forest, in the Imatong Mountains Forest Reserve (450 sq. miles) a region of high mountains, small streams and varied vegetation ${ }^{16}$, and Aza Forest.

Poaching has always been a problem in the Sudan as elsewhere in Africa. At the turn of the century, and probably before, poachers 


\section{TABLE II.-Protected Animals in the Sudan.}

See Page 366 for definition of the schedules.

\section{SCHEDULE I}

Aard wolf

Wild ass

Elephant (tusks less than 5 kilos)

Bald-headed Ibis

Rhinoceros

(all species)

Shoebill stork

(Balaeniceps rex)

\section{Addax}

Addra gazelle

Bongo

Giant bushbuck

Cheetah

Chimpanzee

Yellow-backed duiker

Egret (all species)

Giant eland

Elephant (tusks more than 5 kilos)

Greater flamingo

Lesser flamingo

Giant forest hog

Giraffe

Tora hartebeest

Hoopoe

Ground hornbill

Ibis (all species except bald-headed)

Marabou stork

Colobus monkey

Nile leohwe

Algazal oryx (=scimitar-horned oryx)

Ostrich

Pangolin

Secretary bird

Situtunga

Spoonbill

Saddlebill stork

White stork

Woolly-necked stork
SCHEDULE III

Bushbuck (all species except giant)

Bushpig

Cob (all species)

Dikdik (all species)

Duiker (all species except yellow-backed)

Lesser eland

Gazelle (all species)

Hartebeest (all species except tora)

Hippopotamus

Hyrax

Ibex

Klipspringer

Kudu (all species)

Leopard

Monkey (except colobus)

Oribi

Beisa oryx

Reedbuck

Roan antelope

Wild sheep

Tiang

Warthog

Waterbuck

Wild cats (all species)

Zebra

(From The Preservation of Wild Animals Ordinance 1935)

All species listed under Schedule III may be taken with an ordinary licence excopt hyrax, monkey (except colobus), and wild cats (all species) whose status is uncertain.

crossed over from Ethiopia to hunt in the regions along the border. Game patrols were started before 1910 which helped to limit poaching; there still are patrols in the Dinder National Park, and I am told that poachers rarely cross the border now. It is difficult to assess the extent of poaching in such a large country with so few game scouts for routine patrols. Infringements of game laws certainly occur and many people talk openly about this; probably they have never seen the game ordinances and think that there is little chance of being caught. I have been unable to ascertain the extent of legal hunting in the last fow years, but since the southern provinces were closed there has probably been less hunting on ordinary licences. Special licences (for Schedule II protected animals) are rarely given; Abu Sineina tells me 
that there have been no licences for hunting cheetah for the past ten years.

Special conservation problems arise where national parks or reserves of different countries share a common boundary, e.g. poaching, game migration. The Nimule National Park in Sudan and the Kidepo National Park in Uganda are near to each other. Similarly the Boma Game Reserve in Sudan and the proposed Omo National Park in Ethiopia (Blower in litt.) are almost opposite each other on either side of the Sudan-Ethiopian border. There are several parks and reserves now where Sudan, Ethiopia, Kenya, and Uganda meet; this is good game country, and it might be advisable for the four countries to meet to discuss mutual problems. Now that a Wildlife Conservation Department has been formed in Ethiopia it may be possible to protect the border country more thoroughly ${ }^{15}$. In these circumstances cooperation between countries is essential for the good management of game resources.

It is unfortunate that no Sudanese have been sent for training at the College of African Wildlife Management in Tanzania; places in $19, j$ and 1966 were not taken up (Lamprey in litt.) but it is hoped that the Sudan will send students in 1967. A few graduates from the College could have a most beneficial effect on wildlife protection in the Sudan.

\section{The Future}

The future of large game in the Sudan is in the balance. During the last few years many countries in eastern Africa have made great progress in the conservation and management of game animals, but the Sudan has remained static. Though better off than many African countries - since 1939 there have been parks, reserves and sanctuaries -unless progress is made in the next five to ten years, the Sudan will never become one of the principal game countries as it should be. No doubt depletion of game in the last 50 years has been no greater than elsewhere in Africa, but this is no reason for complacency. It may even be that because of the lack of information and poor communications the game has been less exploited than in better known regions, and the Sudan may now have relatively large stocks of wildlife.

The Game and Fisheries Department knows and appreciates the value of its game $^{20}$ but, unless the Government supplies sufficient staff and funds, it cannot carry out its tasks adequately. At present, the Government does not realise the importance of its game resources, and until this outlook changes no real progress can be made. However, until the "southern problem" is cleared up, little can be done about the parks and reserves in the south. Money is short, and projects that are likely to bring in immediate returns are favoured; expenditure on parks and game would not show any profit for a number of years. Yet in Kenya, tourism is the second largest money earner for the country. 
There will be no real interest in the game or its conservation in the Sudan until up-to-date information is available. The Sudanese people, in particular, must be taught to appreciate their wildlife, and information ought to be sent overseas to attract interest and tourists. Until the Sudan has trained her own wildlife experts and biologists, help might be obtained from international organisations or from countries interested in African wildlife, as Fraser Darling suggested. But any biologists who come to the Sudan must be given a free hand, and their suggestions and advice acted upon, otherwise such aid will be valueless.

It seems to me that the most urgent priorities are :

1. Recognition by the Sudan Government of the value of the wildlife resources of the country and allocation of sufficient funds for the preservation of wildlife. Any future land development should take into account the wildlife value of such land.

2. Recognition and implementation of the Fraser Darling report, especially the education of the Sudanese people to know and to appreciate their wildlife resources, and to show that the Sudan is one of the principal game countries of Africa.

This report is not as comprehensive or informed as I originally hoped; but lack of information and the impossibility of travelling in the three southern provinces, has prevented a more detailed survey. However, it is hoped that it will stimulate interest in the wild life of the Sudan, and help the cause of conservation in the country.

\section{Append $1 x$}

\section{A VISIT TO THE DINDER NATIONAL PARK}

In January 1966, it took one-and-a-half days' hard driving over generally bad roads to cover the $\mathbf{3 2 0}$ miles from Khartoum. South of Senaar and the Gezira irrigation scheme, Acacia seyal, Acacia fistula, Balanites and Combretum begin to appear and later form a dense savanna woodland. The grasses had been burned in many places along the roadside - a common practice even though there will be no rains until about June-so the country looked black and desolate. In December, flying over the Rahad and Dinder rivers we had seen smoke and fires and most of the ground appeared black. In the dry bed of the Dinder river, which we crossed several times, herds of cattle and sheep were being watered in the remaining puddles. No game animals were seen before the park was reached. The sudden appearance of game is very noticeable when you get there although there is no notice to mark the entrance to, and northern limit of, the park. Only a few local inhabitants were seen in the last $\mathbf{4 0}$ miles, some on camels, others carrying spears and herding sheep.

The headquarters of the park are at Galegu, once a village but now inhabited only by the park authorities, on the east bank of the wide Dinder river, here divided into two by an island. In January the river 
is dry and sandy except for occasional large pools trequented by waterbirds and game. There are no permanent buildings, just large tents and grass 'raboubas' (huts). Visitors are allocated a tent and a rabouba for a kitchen, and water can be obtained from a hole dug in the dry river bed. All transport, petrol, camping equipment and food must be brought. Some large trees give some shade, but it can be very hot in the middle of the day. The green tents of a safari firm which now runs four-day trips from Khartoum, with everything supplied, are pitched near the headquarters. The park entrance fees are $f 1$ per person, $f 2$ per vehicle, and $£ 1$ for a game scout (compulsory) in each car per day.

The park is open from late December until May, during which two patrols, each of twelve camels, go out on continuous 15 . 20-day patrols in the border country, and twelve polioemen are seconded to the park to help with patrolling and escorting visitors. From June to December, during and immediately after the rains, the cotton soil makes travel impossible, and all the park staff leave in May. I was told that poaching was almost non-existent in these months since many game animals have moved out of the park, and even travel on camels is difficult. The graded tracks in the park wind through the Acacia and Combretum trees, or among the dom palms beside the Dinder river. In parts the dried grasses have been burned intentionally as park policy. The largest concentrations of game are to be seen, grazing peacefully among black-headed herons, storks, egrets, and vultures, in three swampy areas covered with green grasses and encircled by trees.

On six drives taken in the park between January 21 and 24 within 16 miles of the headquarters at Galegu we saw over 1700 animals of ten species: baboon, grivet and red hussar monkeys, warthog, buffalo, waterbuck, reedbuck, roan antelope, tiang and oribi. At the same time Dr. A. Pettet, of the University of Khartoum, reconded 115 species of birds. At other times I saw two honey badgers Mellivora capensis and a dead porcupine; lions, giraffe, and lesser kudu were seen by other people during the same few days. The park is remote and undeveloped at present, and perhaps this is one of its attractions. Many of the herds are most impressive, and the park could become a fascinating region, as important as the well known parks of East Africa.

\section{Acknowledgments}

I should like to thank Mr. Mahmoud Abu Sineina, Assistant Director (Game), Sudan, for answering many of my questions and for giving up some of his valuable time. I am also grateful to Dr. F. Fraser Darling, Lt. Col. P. G. Molloy (ex Game Warden in the southern Sudan), Mr. M. K. Shawki (Director, Forest Department, Khartoum, and a Vice President of IUCN), and Mr. Mahmoud Abu Sineina for their comments on the manuscript. The University of Khartoum provided funds for most of my travels in the Sudan. 


\section{REFERENCES}

1 ANDERSON, A. B. 1950. The Sudan's Southern National Park, Sudan Wildl. \& Sport 1(3): 12-16.

2 ANONYMOUS 1952. Bird sanctuary for the Three Towns. Sudan Wildl. \& Sport 2(3):5-9.

3 AUDAS, R. S. 1919. Oryx hunting in northern Darfur. Sudan Notes \& Records $2: 20-23$.

4 AUDAS, R. S. 1951. Game in northern Darfur. Sudan Wildl. \& Sport 2(1):11-14.

5 BROCKLEHURST, H. C. 1931. Game Animals of the Sudan. London.

6 BUDGE, A. 1911. Cook's Handbook for Egypt and the Egyptian Sudan. 3rd Edn. London.

7 CAVE, F. O. and CRUIKSHANK, A. 1940. A note on game migration in the S-E Sudan. Sudan Notes \& Records $23: 341-344$.

8 CAVE, F. O. and MACDONALD, J. D. 1955. Birds of the Sudan. Edinburgh.

9 CHAPMAN, A. 1921. Savage Sudan. London.

10 CRUIKSHANK, A. 1962. The Kindling Fire. London.

11 DICKINSON, F. A. 1910. Lake Victoria to Khartoum. London.

12 ENGELHARDT, W. 1962. Survival of the Free. London.

13 FRASER DARLING, F. 1961. Towards a game policy for the Sudan. Mimeo. 31 pp.

14 HAPPOLD, D. C. D., 1966. Mammals of Jebel Marra, Sudan. J. Zool., Lond., 149, 126-136.

15 HUXLEY, J., GILLE, A., MONOD, T., SWIFT, L., and WORTHINGTON, E. B. 1963. The conservation of nature and natural resources in Ethiopia. UNESCO/NS/NR/47, Paris.

16 JACKSON, J. K. 1953. The Imatong Mountains Forest Reserve. Sudan Wildl. \& Sport 3(1): 10-14.

17 LYTH, R. E. 1947. The migration of game in the Boma area. Sudan Notes \& Records 28:191-192.

18 MILLAIS, J. G. 1924. Far away up the Nile. London.

19 MOLLOY, P. 1957. The Cry of the Fish Eagle. London.

20 NABI, A. A. 1956. Protection of Game in the Sudan. Sudan Notes \& Records 37:119-121.

21 OWEN, T. R. H. 1949. The Nimule Corridor. Sudan Wildl. \& Sport 1(2):33-36.

22 SCHOMBER, H. W. 1962. Wildlife Protection in the Sudan. II. The National Parks and Game Reserves. Afr. Wildl. 16(3):205-212.

23 SCHOMBER, H. W. 1963. Wildlife in the Sudan. IV. Desert and semidesert game animals, Afr. Wildl. 17(2)117-124.

24 SETZER, H. W. 1956. Mammals of the Anglo-Egyptian Sudan. Proc. U.S. Nat. Mus. 106:447-587.

25 SUDAN, REPUBLIC OF, 1960. The Preservation of Wild Animals Ordinance and Regulations 1935. Amended to 30 November 1960. Ministry of Animal Resources, Khartoum. 29 pp.

26 TALBOT, L. M. 1960. A look at threatened species. Oryx 5:153-293.

27 WHALLEY, R. C. R. 1932. Southern Sudan Game and its habitat. Sudan Notes \& Records. 15:261-267.

28 WOODMAN, H. M. 1965. What of the Sudan game migration? Oryx $8: 113-114$. 